\title{
PERMOHONAN SURAT IZIN PRAKTIK BIDAN (SIPB) BERDASARKAN PERATURAN \\ MENTERI KESEHATAN NO. 1464/MENKES/PER/X/2010 TENTANG IZIN DAN PENYELENGGARAAN PRAKTIK BIDAN DI KABUPATEN BREBES Oleh: Diana Novy Fikria
}

\begin{abstract}
ABSTRAK
Bidan sebagai salah satu tenaga kesehatan dalam menyelenggarakan praktik kebidanannya wajib memiliki izin dari pemerintah dalam bentuk Surat Izin Praktik Bidan. Salah satu syarat untuk mendapatkan SIPB yaitu rekomendasi dari organisasi Profesi ikatan Bidan Indonesia. Rekomendasi IBI di Kabupaten Brebes dapat diperoleh jika anggota sudah memiliki sertifikat Contraception technology Update. CTU tidak selaras dengan kewenangan Bidan yang terdapat dalam Peraturan Menteri Kesehatan No.1464/Menkes/Per/X/2010 tentang Izin dan Penyelenggaraan Praktik Bidan.

Penelitian ini bertujuan untuk menganalisa permohonan Surat Izin Praktik Bidan dan untuk menganalisa kendala-kendala yang menghambat permohonan SIPB berdasarkan Peraturan Menteri Kesehatan No.1464/Menkes/Per/X/2010 tentang Izin dan Penyelenggaraan Praktik Bidan.Penelitian ini merupakan penelitian kualitatif dengan pendekatan yuridis sosiologis.

Hasil menunjukkan bahwa permohonan SIPB di Kabupaten Brebes belum sepenuhnya sesuai dengan Permenkes No. 1464/Menkes/Per/X/2010 tentang Izin dan Penyelenggaraan Praktik Bidan. Hambatannya yaitu untuk mendapatkan rekomendasi dari IBI anggota harus mengikuti pelatihan CTU, kepatuhan anggota dalam mengumpulkan persyaratan permohonan SIPB berbeda-beda yang mengakibatkan proses pengajuan berlangsung lama serta adanya kebijakan dari Dinas Kesehatan dan IBI Kabupaten Brebes yang memberlakukan dua kewenangan SIPBAnte Natal Care dan Post Natal Care dan SIPB ANC, INC dan Intra Natal Care.
\end{abstract}

Kata Kunci: kesehatan, ijin, praktikbidan

\section{ABSTRACT}

Midwives as one ofthe health workers in the organized practice of compulsory kebidanannya has permission from the Government in the form of License the practice of Midwives. One of midwives ties Indonesia. Recommendation IBI in Brebes Regency can be obtained if the Member already has a certificate of Contraception technology updates. CTU is not aligned with the the conditions to get the SIPB i.e. the recommendations of professional organizations of authority contained in the regulation of midwives, the Minister of health no. 1464/Menkes/Per/X/2010 about permitsand Conducting the practice of Midwives.

This research aims to analyze the petition Passes the practice of midwives and to analyze the constraints that hinder the application based Regulations SIPB Minister of health no. 1464/Menkes/Per/X/2010 about permits and Conducting the practice of Midwives. This research is qualitative research with the juridical sociological approach.

The results show that the petition SIPB in Brebes Regency have not fully in accordance with Permenkes No. 1464/Menkes/Per/X/2010 about permits and Conducting the practice of Midwives. Resistance to get recommendations from IBI members must attend training CTU,compliance requirement application in collecting Member SIPB vary resulting in a filing process lasts a long time as well as the policies of the health service and IBI B rebes Regency that enforces two Ante Natal Care SIPB authority and Post Natal Care and the SIPB ANC, INC. and Intra Natal Care.

Keyword: health, permited, midwive 


\section{A. Latar B elakang}

Pembangunan kesehatan pada hakekatnya diarahkan guna tercapainya kesadaran kemauan serta kemampuan hidup sehat bagi setiap orang baik menyangkut fisik, mental maupun sosial budaya dan ekonomi. Untuk mencapai derajat yang optimal dilakukan berbagai upaya pelayanan kesehatan yang menyeluruh, terarah dan berkesinambungan. Tercapainya derajat kesehatan masyarakat yang optimal adalah salah satu tujuan dari pembangunan kesehatan. Untuk mewujudkan tujuan tersebut maka diperlukan sumber daya kesehatan yang cukup dan adanya dukungan peran serta aktif dari masyarakat maupun swasta dalam penyelenggaraan upaya kesehatan. Sumber daya kesehatan yang utama adalah tenaga kesehatan yang cukup dan mempunyai keahlian dibidangnya. Tanpa adanya dukungan tenagakesehatan yang berkualitas tidak mungkin tujuan pembangunan kesehatan tercapai. $^{1}$

Bidan adalah salah satu tenaga kesehatan yang mempunyai peran penting dalam upaya mewujudkan pembangunan kesehatan terutama dibidang kesehatan ibu dan anak. Bidan dalam menjalankan kewenangannya harus memiliki izin praktik. Untuk memperoleh Surat Izin Praktik Bidan (SIPB), Bidan harus meng-

Soekidjo Notoatmodjo, 2010, Etika dan Hukum Kesehatan, Rineka Cipta, Jakarta, Hal.55 ajukan permohonan kepada pemerintah daerah kabupaten/kota dengan melampirkan :2

a. Fotocopy Surat Tanda Registrasi (STR) yang masih berlaku dan dilegalisasi

b. Surat keterangan sehat fisik dari dokter yang memiliki Surat Izin Praktik

c. Surat pernyataan memiliki tempat kerja di fasilitas pelayanan kesehatan atau tempat praktik

d. Pas foto berwarna terbaru ukuran $4 \times 6 \mathrm{~cm}$ sebanyak tiga (3) lembar

e. Rekomendasi dari kepala dinas kesehatan kabupaten/kota atau pejabat yang ditunjuk, dan

f. Rekomendasi dari organisasi profesi.

Jumlah Bidan di Kabupaten Brebes ada sekitar 1085 orang bidan, 800 orang memiliki SIPB yang pada tahun 2015 beberapa Bidang ada yang ingin mengajukan permohonan guna memperoleh SIPB dan ada pula yang mengajukan perpanjangan SIPB. Rekomendasi dari Organisai Profesi yang dalam hal ini Ikatan Bidan Indonesia (IBI) mutlak diperlukan sebagai syarat permohonan SIPB. Untuk memperoleh rekomendasi dari $\mid \mathrm{BI}$ anggota wajib mengikuti pelatihan Contraception Technology Update/CTUterlebih dahulu. Hal ini tidak selaras jika dikaitkan dengan persyaratan untuk memperoleh rekomendasi dari organisasi profesi, karena tidak semua

Permekes 1464/Menkes/Per/X/2010, tentang Izin dan Penyelenggaraan Praktik bidan Pasal 
377 | J urnal Idea Hukum

Vol. 2 No. 2 Oktober 2016

Magister Hukum Fakultas Hukum Universitas J enderal Soedirman

bidan praktik mandiri di kabupaten

Brebes ditugaskan untuk melaksanakan program pemerintah.

Pasal 86 (1) UU No. 36 tahun 2014 tentang tenaga kesehatan bahwa Setiap tenaga kesehatan yang menjalankan praktik tanpa memiliki izin dipidana dengan pidana denda paling banyak Rp100.000,000,(seratus juta rupiah). Uraian tersebut menarik penulis untuk melakukan penelitian mengenai Pelaksanaan Peraturan Menteri Kesehatan Nomor1464/MENKES/PER/X/2010 tentang Izin dan Penyelenggaraan Praktik Bidan Di Kabupatan Brebes.

\section{B. Perumusan Masalah}

Rumusan masalah dalam pene-litian ini adalah:

1. Bagaimana permohonan Surat Izin Praktik Bidan (SIPB) berdasarkan Peraturan Menteri Kesehatan No.

1464/MENKES/PER/X/2010 tentang Izin dan Penyelenggaraan Praktik Bidan di Kabupaten Brebes?

2. Apakahkendala-kendala yang menghambat permohonan Surat Izin Praktik Bidan (SIPB) berdasarkan Peraturan Menteri Kesehatan Nomor

1464/MENKES/PER/X/2010

tentang Izin dan Penyelenggaraan Praktik Bidan di Kabupaten Brebes?

\section{Tujuan Penelitian}

1. Untuk menganalisa permo-honan Surat Izin Praktik Bidan (SIPB) berdasarkan Peraturan Menteri

Kesehatan

Nomor

1464/MENKES/PER/X/2010 tentang Izin dan Penyeleng-garaan, Praktik Bidan di Kabupaten Brebes.

2. Untuk menganalisa kendalakendala yang menghambat permohonan Surat Izin Praktik Bidan (SIPB) berda-sarkan Peraturan Menteri Kesehatan Nomor

1464/MENKES/PER/X/2010 tentang Izin dan Penyelenggaraan Praktik Bidan di Kabupaten Brebes.

Kewenangan memiliki kedudukan penting dalam kajian hukum tata negara dan hukum administrasi. Secara teoritik, ada tiga macam kewenangan yang bersumber dari peraturan per-undang-undangan yang diperoleh melalui atribusi, delegasi, dan mandat. ${ }^{3}$ Indroharto mengatakan bahwa pada atribusi terjadi pemberian wewenang pemerin-tahan yang baru oleh suatu ketentuan dalam peraturan perundang-undangan.

Berdasarkan Peraturan Men-teri Kesehatan (Permenkes) Nomor 1464/Menkes/Per/X/2010 tentang Izin dan Penyelenggaran Praktik

Ridwan HR, 2008, Hukum Administrasi Negara, Raja Grafindo Persada, Jakarta, Hal. 104. 
Bidan, kewenangan yang dimiliki bidan meliputi:

1. Kewenangan normal:

a. Pelayanan kesehatan ibu

b. Pelayanan kesehatan anak

c. Pelayanan kesehatan reproduksi perempuan dan keluarga berencana

2. Kewenangan dalam menja-lankan program Pemerintah.

3. Kewenangan bidan yang menjalankan praktik di daerah yang tidak memiliki dokter.

Selain kewenangan normal sebagaimana tersebut di atas, khusus bagi bidan yang menjalankan pro-gram pemerintah mendapat kewe-nangan tambahan untuk melakukan pelayanan kesehatan yang melipu-ti: ${ }^{4}$

1. Pemberian alat kontrasepsi suntikan, alat kontrasepsi dalam rahim, dan memberikan pela-yanan alat kontrasepsi bawah kulit.

2. Asuhan antenatal terintegrasi dengan intervensi khusus pe-nyakit kronis tertentu (dilakukan di bawah supervisi dokter).

3. Penanganan bayi dan anak balita sakit sesuai pedoman yang ditetapkan.

4. Melakukan pembinaan peran serta masyarakat di bidang kesehatan ibu dan anak, anak usia sekolah dan remaja, dan penyehatan lingkungan.

5. Pemantauan tumbuh kembang bayi, anak balita, anak pra sekolah dan anak sekolah.

6. Melaksanakan pelayanan kebidanan komunitas.

7. Melaksanakan deteksi dini, merujuk dan memberikan penyuluhan terhadap Infeksi Menular Seksual (IMS) termasuk pemberian kondom, dan penyakit lainnya.

8. Pencegahan penyalahguna-an Narkotika, Psikotropika dan Zat

4 Permenkes 1464, Op.Cit, Pasal 13
Adiktif lainnya (NAPZA) melalui informasi dan edukasi.

9. Pelayanan kesehatan lain yang merupakan program Pemerin-tah.

\section{Asuhan Persalinan Normal (APN)}

Dasar pelatihan klinik Asuhan Persalinan Normal (APN) adalah asuhan yang bersih daan aman dari setiap tahapan persalinan dan upaya pencegahan komplikasi terutama perdarahan pascapersalinan dan hipotermiaserta asfiksia bayi baru lahir. ${ }^{5}$ Tujuan Asuhan Persalinan Normal adalah menjaga kelangsungan hidup dan memberikan derajat kesehatan yang tinggi bagi ibu dan bayinya, melalui upaya yang terintegrasi dan lengkap tetapi dengan intervensi yang seminimal mugkin agar prinsip keamanan dan kualitas pelayann dapat terjaga pada tingkat yang diinginkan (optimal). Dengan pendekatan seperti ini, berarti bahwa setiap intervensi yang diaplikasikan dalam Asuhan Persalinan Normal harus mempunyai alasan dan bukti ilmiah yang kuat tentang manfaat intervensi tersebut bagi kemajuan adan keberhasilan proses persalinan. ${ }^{6}$

\section{Perizinan Bidan}

Izin adalah perangkat hukum administrasi yang digunakan pemerintah untuk mengendalikan warganya agar berjalan dengan teratur. Menurut Sjachran Basah,izin adalah perbuatan hukum administrasi negara bersegi satu yang menghasilkan peraturan dalam hal

\footnotetext{
5 JNPK-KR, 2008, Pelatihan Klinik Asuhan Persalinan Normal, Jakarta. Hal.2 6 Ibid, Hal. 3
} 
379 | J urnal Idea Hukum

Vol. 2 No. 2 Oktober 2016

Magister Hukum Fakultas Hukum Universitas J enderal Soedirman

konkreto berdasarkan persyaratan dan prosedur sebagaimana ditetapkan oleh ketentuan perundang-undangan. ${ }^{7} \mathrm{E}$. Utrecht,mengatakan bahwa bilamana pembuat peraturanumumnya tidak melarang sutau perbuatan, tetapi masih juga memperkenankannya asal saja diadakan secara yang ditentukan untuk masing-masing hal kongkret, maka keputusan administrasi negara yang memperkenankan perbuatan tersebut bersifat suatu izin (vergunning). ${ }^{8}$

\section{Bekerjanya Hukum}

Pendekatan model Seidman bertumpu pada fungsinya hukum, berada dalam keadaan seimbang. Artinya hukum akan dapat bekerja dengan baik dan efektif dalam masyarakat yang diaturnya. Memandang efektifitas hukum dan bekerjanya hukum dalam masyarakat perlu memperhatikan hal-hal sebagai berikut. Pertama, lembaga pembuat peraturan; apakah lembaga ini merupakan kewenangan maupun legitimasi dalam membuat aturan atau undang-undang. Berkaitan dengan kualitas materi normatifnya, apakah sudah memenuhi syarat dan jelas perumusannya. Kedua, pentingnya penerap peraturan; pelaksana harus tegas melaksanakan perintah undang-undang tanpa diskriminasi atau equal justice under law. Ketiga, pemangku peran; diharapkan mentaati hukum, idealnya

7 Sjachran Basah, 1995,Pencabutan Izin Sebagai Salah Satu Sanksi Hukum Administrasi Negara, FH UNAIR, Surabaya, Hal 4

8 Ridwan HR, 2003,. Hukum Administrasi Negara.,UII Press, Yogyakarta, Hal. 153 dengan kualitas internalization. Perilaku dan reaksi pemangku peran merupakan umpan balik kepada lembaga pembuat peraturan maupun pelaksanan peraturan. Apakah kedua elemen tersebut telah melakukan fungsinya dengan optimal. ${ }^{9}$ Hukum dapat bekerja dan berfungsi tidak sekedar apa yang diharapkan oleh pembuat peraturan hukum, tetapi perlu diteliti pada komponen elemen yang tidak bekerja sebagaimana mestinya. Maksudnya tidak bekerja itu, bisa datangnya dari pembuat peraturan hukum, atau dari para penerap peraturan/pelaksana, ataukah dari pemangku peran. Selain itu dapat dikaji kendala-kendala eksternal global yang menyebabkan hukum tidak dapat dilaksanakan sebagaimana mestinya. Seperti ada tekanan-tekanan dari pihak luar negeri yang tergabung dalam organisasi internasional. ${ }^{10}$

Peranan dari kekuatan sosial yang tidak hanya berpengaruh terhadap rakyat sebagai sasara yang diatur oleh hukum, melainkan juga terhadap lembaga-lembaga hukum. Kekuatan sosial termasuk tatanan lain yang kompleks yang dibicarakan. Hasil akhir dari pekerjaan tatanandalam masyarakat tidak hanya dimonopoli oleh hukum melainkan juga kekuatan sosial lainnya. $^{11}$

\footnotetext{
Achmad Ali dan Wiwie Heryani, 2012, Menjelajahi Kajian Empiris Terhadap Hukum, Prendamedia, Jakarta, Hal. 14.

10 Ibid, Hal. 28

11 Satjipto Rahardjo, 2000, IImu Hukum, PT. Citra Aditya Bakti, Bandung, Hal.55
} 


\section{Metode Penelitian}

Tipe penelitian ini adalah diskriptif analitis, yaitu data yang dinyatakan oleh responden secara tertulis atau lisan serta juga tingkah laku yang nyata,yang diteliti dan dipelajari sebagai sesuatu yang utuh guna mendapatkan deskripsi tentang permohonan Surat Izin Praktik Bidan (SIPB) di Kabupaten Brebes berdasarkan Peraturan Menteri Kesehatan Nomor 1464/MENKES/PER/X/2010 tentang Izin dan Penyelenggaraan Praktik Bidan.Metode pendekatan yang digunakan dalam penelitian ini adalah yuridis sosiologis. Data yang telah dikumpulkan dari penelitian selanjutnya dianalisis secara deskriptif kualitatif. ${ }^{12}$

\section{E. Pembahasan}

1. Permohonan Surat Izin Praktik Bidan (SIPB) Berdasarkan Peraturan Menteri Kesehatan Nomor

1464/ME NKES/PE R/X/2010 $\begin{array}{ll}\text { Tentang Izin Dan } \\ \text { Penyelenggaraan } & \text { Praktik }\end{array}$ Bidan Di Kabupaten B rebes.

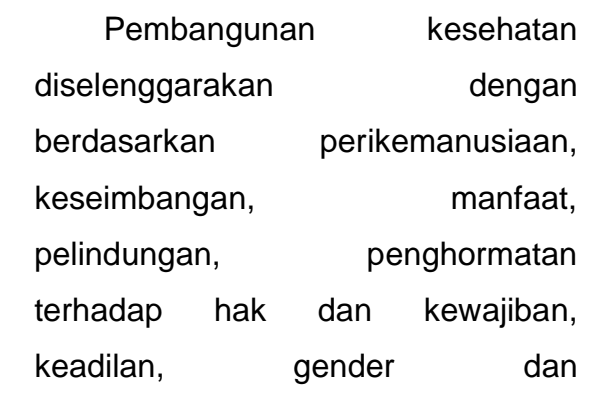

12 Soerjono Soekanto dan Sri Mamudji, 2007, Penelitian Hukum Normatif Suatu Tinjauan Singkat, PT Raja Grafindo Persada, Jakarta, hal 250 nondiskriminatif, dan norma-norma agama. $^{13}$

Pasal 23 UU No. 36 Tahun 2009 Tentang Kesehatan menyebutkan bahwa tenaga kesehatan dalam menyelenggarakan pelayanan kesehatan, wajib memiliki izin dari pemerintah. Bidan adalah salah satu tenaga kesehatan yang mempunyai peran penting dalam upaya mewujudkan pembangunan kesehatan terutama dibidang kesehatan ibu dan anak. Bidan dalam menjalankan kewenangan nya harus memiliki izin praktik. Untuk memperoleh Surat Izin Praktik Bidan (SIPB), Bidan harus mengajukan permohonan kepada pemerintah daerah kabupaten/kota. ${ }^{14}$

Hukum dapat dipahami sebagai sarana/alat untuk mengatur masyarakat. Pengertian ini mengaitkan hukum untuk mencapai tujuan-tujuan serta memenuhi kebutuhan konkrit dalam masyarakat. ${ }^{15}$

Berdasarkan data hasil penelitian yang diperoleh dengan melakukan wawancara kepada informan dan kuesioner terhadap tiga puluh Bidan diperoleh hasil sebagai berikut:

13 Undang-Undang Nomor 36 Tahun 2009 Tentang Kesehatan Pasal 2

14 Permekes 1464/Menkes/Per/X/2010, tentang Izin dan Penyelenggaraan Praktik bidan Pasal 4

15 Esmi Warasih, 2005, Pranata Hukum Sebuah Telaah Sosiologis, PT. Suryandaru Utama, Semarang, Hal.23 
381 | J urnal Idea Hukum

Vol. 2 No. 2 Oktober 2016

Magister Hukum Fakultas Hukum Universitas J enderal Soedirman

\begin{abstract}
a. Kepemilikan SIPB
Dari tiga puluh

Responde/Bidan Praktik mandiri, dua belas orang atau $40 \%$ SIPB masa berlakunya telah habis dan delapan belas orang atau $80 \%$ lainnya SIPB masih berlaku, ratarata sampai dengan Juni 2016.Berdasarkan Permenkes 1464/Menkes/Per/x/2010 Pasal 3
\end{abstract} (1) bahwa setiap bidan yang bekerja di fasilitas pelayanan kesehatan wajib memiliki SIKB (Surat Izin Kerja Bidan); Pasal 3 (2) bahwa setiap bidan yang menjalankan praktik mandiri (BPM) wajib memiliki SIPB (Surat Izin Praktik Bidan). Ketentuan perizinan tenaga kesehatan diatur dalam UU Nomor 36 Tahun 2009 tentang kesehatan, Pasal 23 bahwa tenaga kesehatan dalam menyelenggarakan pelayanan kesehatan, wajib memiliki izin dari pemerintah. Selama memberikan pelayanan kesehatan dilarang mengutamakan kepentingan yang bernilai materi. Ketentuan mengenai perizinan diatur dalam Peraturan Menteri.

Dari hasil penelitian tentang Permohonan SIPB berdasarakan Permenkes

1464/Menkes/Per/X/2010 tentang izin dan penyelenggaraan praktik bidan di Kabupaten Brebes tentang kepemilikan SIPB dapat dianalisa bahwatujuan hukum dari segi ketertiban belum tercapai hal ini teranalisa dari adanya dua belas bidan yang SIPB nya telah habis masa berlakunya dan belum mendapatkan SIPB karena persyaratan permohonan SIPB dilakukan secara kolektif per ranting tiap kecamatan yang mengakibatkan proses permohonan menjadi lama serta terkendala sulitnya mendapat rekomendasi dari IBI karena harus mengikuti pelatihan CTU. Kepemilikan Surat Izin Praktik Bidan bentuk ketertiban dan kemakmuran dalam penyelenggara an praktik kebidanan sebagai salah satu tujuan hukum. Dari 12 bidan berlakunya sampai saat ini masih menyelenggarakan praktik kebidanan tanpa memiliki SIPB.

Sesuai dengan lampiran Per-menkes 1464Menkes/Per/X/2010 di-sebutkan bahwa untuk tempat untuk praktik bidan mandiri terpisah dari ruangan keluarga yang terdiri yang SIPB nya telah habis masa berlakunya sampai saat ini masih menyelenggarakan praktik kebidanan tanpa memiliki SIPB.

Berdasarkan UU RI Nomor 36 Tahun 2014 tentang Tenaga Kesehatan Pasal 82 bahwa setiap tenaga kesehatan yang melaksanakan praktik tidak memenuhi persyaratan dikenai sanksi administrasi, sanksi administrasi tersebut dapat berupa teguran lisan, teguran tertulis, denda administrasi, dan/atau pencabutan izin. Pasal 86 (1) UU 
No 36 tahun 2014 tentang tenaga kesehatan bahwa setiap tenaga kesehatan yang menjalankan praktik tanpa memiliki izin dipidana dengan pidana denda paling banyak Rp100.000,000,- (seratus juta rupiah).

\section{b. Kepemilikan tempat praktik}

Sesuai dengan lampiran Permenkes

1464Menkes/Per/X/2010 disebutkan bahwa untuk tempat untuk praktik bidan mandiri terpisah dari ruangan keluarga yang terdiri dari:

a. Ruang tunggu

b. Ruang pemeriksaan

c. Ruang persalinan

d. Ruang rawat inap

e. WC/kamar mandi

f. Ruang pencegahan dan pengendalian infeksi (PPI)

Hasil observasi di tiga puluh lokasi praktik bidan mandiri diketahui bahwa 21 BPM memiliki tempat praktik sesuai dengan Permenkes 1464Menkes/Per/X/2010 dan sembilan lainnya belum sesuai. Sembilan BPM yang belum sesuai tempat praktiknya hanya memiliki ruang tunggu, ruang pemeriksaan, WC/kamar mandi. Persalinan, rawat inap dan pencegahan infeksi dilakukan di ruang pemeriksaan. Pada dasarnya Permenkes 1464/Menkes/Per/X/2010 mengharuskan BPM mempu- nyai tiga ruang untuk praktik yaitu ruang pemeriksaan, ruang persalinan dan ruang rawat inap. Adanya peraturan tersebut maka BPM wajib memiliki tiga ruang tersebut sebagai salah satu syarat pembuatan SIPB. Dinas Kesehatan Kabupaten Brebes memberikan kebijakan dengan mengeluarkan duakewenangan SIPB yaitu SIPB yang hanya melayani pemeriksaan kehamilan normal dan nifas normal (SIPB ANC/Ante Natal Caredan PNC/P ost Natal care) dan SIPB yang melayani pemeriksaan kehamilan normal dan persalinan dan nifas normal (SIPB ANC INC PNC/ Ante Natal Care, Intra Natal care dan Post Natal Care).

Dari hasil penelitian tentang Permohonan SIPB berdasarkan Permenkes 1464/Menkes/Per/X/2010 tentang izin dan penyelenggaraan praktik bidan di Kabupaten Brebes tentang kepemilikan tempat praktik dapat dianalisa bahwa berdasarkan teori etis yang menngemukakan bahwa hukum itu semata-mata ber-tujuan untuk menemukan keadil-an. Isi hukum ditentukan oleh keyakinan yag etis tentang apa yang adil dan tidak adil. Dengan perkataan lain, hukum bertujuan 
383 J urnal Idea Hukum

Vol. 2 No. 2 Oktober 2016

Magister Hukum Fakultas Hukum Universitas J enderal Soedirman

untuk merealisasikan atau me-

wujudkan keadilan. ${ }^{16}$ Menurut

Hans Kelsen, suatu peraturan

umum dikatakan adil jika benar-

benar diterapkan kepada semua kasus, yang menurut isinya peraturan ini harus diterapkan. Suatu peraturan umum dikatakan tidak adil jika diterapkan kepada suatu kasus dan tidak diterapkan kepada kasus lain yang sama. ${ }^{17}$

Menurut Sudikno Mertokusumo, tujuan hukum adalah menciptakan tatanan masyarakat yang tertib, dengan menciptakan ketertiban dan keseimbangan dalam masyarakat. ${ }^{18}$ Teori campuran menjelaskan bahwa tujuan pokok hukum adalah ketertiban, dan oleh karena itu ketertiban merupakan syarat bagi adanya suatu masyarakat yang teratur. Van Apeldoorn berpendapat bahwa pada dasarnya hukum bertujuan untuk mengatur pergaulan hidup manusia secara damai. Soebekti berpendapat bahwa hukum itu mengabdi kepada tujuan negara untuk mendatangkan kemakmuran bagi rakyatnya. $^{19}$

Tujuan hukum dari segi keadilan dalam penelitian ini

Ibid, Hal.24.

Yunasril Ali, 2009, Dasar-dasar IImu Hukum, Sinar Grafika, Jakarta, Hal. 33

Ibid, Hal.27

9 Esmi Warasih, Op.Cit, Hal. 27 belum tercapai, hal ini teranalisa dari masih adanya sembilan bidan yang belum memiliki tempat yang sesuai standar tetapi masih tetap menyelenggarakan praktik kebidanan. Penyelenggaraan praktik kebidanan adalah upaya pelayanan dalam kesehatan ibu dan anak serta kesehatan reproduksi. Untuk mewujudkan upaya tersebut peran dari bidan praktik mandiri sangatlah penting. Bidan dalam menjalankan praktik kebidanannya harus meiliki kriteria tempat praktik yang sesuai standar Permenkes 1464/Menkes/Per/X/2010.

Adanya dua kebijakanSIPB ANC PNC dan SIPB ANC INC PNCdari Dinas Kesehatan Kabupaten Brebes akan tujuan hukum untuk menemukan keadilan belum tercapai. Seharusnya bidan praktik yang akan menyelenggarakan praktik kebidanan harus memiliki tempat praktik dan mempunyai kewenangan yang sama sesuai dengan Permenkes 1464/Menkes/Per/X/2010 tentang Izin dan Penyelenggaraan Praktik Bidan.

\section{Rekomendasi organisasi profesi (IBI)}

Rekomendasi IBI mutlak diperlukan dalam pengajuan permohonan SIPB baru atau pembaruan SIPB. Di Kabupaten Brebes untuk mendapatakan 
rekomendasi IBI wajib memiliki sertifikat Asuhan Persalinan Normal (APN) dan sertifikat CTU (Conteception Technology Update).

Tiga puluh bidan seluruhnya $100 \%$ memiliki sertifikat APN. Asuhan persalinan normal merupakan kompetensi yang harus dimiliki Bidan. Dari tiga puluh responden lima belas orang sudah memiliki sertifikat CTU dua belas diantaranya bekerja di puskesmas sebagai Bidan PNS (Pegawai negeri Sipil) dan Bidan PTT (Pegawai Tidak Tetap/Bidan Desa) memiliki sertifikat tersebut dengan mengikuti pelatihan CTU yang dibiayai oleh pemerintah, dan tiga lainnya adalah Bidan swasta yang bekerja di Rumah Sakit Pemerintah dan Rumah Sakit swasta dengan biaya sendiri.

$$
\text { Berdasarkan permenkes }
$$

1464/menkes/per/X/2010 Pasal 13 bahwa kewenangan pemasangan implan dan IUD ini hanya untuk bidan yang menjalankan program pemerintah. Pasal 15 (1) Pemerintah daerah provinsi/kabupaten/kota menugaskan bidan praktik mandiri tertentu untuk melaksanakan program pemerintah. Pasal 15 (2) Bidan praktik mandiri yang ditugaskan sebagai pelaksana program pemerintah berhak atas pelatihan dan pembinaan dari pemerintah daerah provinsi/kabupaten/kota.

Dari hasil penelitian tentang Permohonan SIPB berdasarkan Permenkes 1464/Menkes/Per/X/2010 tentang izin dan penyelenggaraan praktik bidan di Kabupaten Brebes tentang kepemilikan sertifikat APN dan CTU dapat dianalisa bahwa belum memenuhi azas hukum. Lon L. Fuller berpendapat bahwa untuk mengenal hukum sebagai sistem maka harus memenuhi 8 azas atau principles of legality berikut ini: ${ }^{20}$

1) Sistem hukum harus mengandung per-aturan-peraturan artinya ia tidak boleh mengandung sekedar keputusan-keputusan yang bersifat ad.hoc.

2) Peraturan-peraturan yang telah dibuat itu harus diumumkan.

3) Peraturan tidak boleh berlaku surut.

Bidan dalam surat pernyataan sanggup tunduk pada peraturan yang berlaku, tugas dan kewenangan bidan masih mengacu pada Kepmenkes RI Nomor: 900/Menkes/SK/VII/2002 bukan pada Permenkes 1464/Menkes/Per /X/2010. Kepmenkes RI Nomor: 900/Menkes/SK/VII/2002 pemasangan dan pencabutan IUD dan implan merupakan kewenangan BPM. Permenkes 1464/Menkes/Per/x/2010 kewenangan pemasangan dan pencabutan IUD dan Implan hanya untuk bidan yang menjalankan program pemerintah.

Peraturan-peraturan disusun dalam rumusan yang bisa dimengerti. Suatu sistem tidak boleh mengandung peraturan-peraturan yang bertentangan satu sama lain.

\footnotetext{
20 Ibid, Hal.31
} 
385 | J urnal Idea Hukum

Vol. 2 No. 2 Oktober 2016

Magister Hukum Fakultas Hukum Universitas J enderal Soedirman

Kewenangan pemasanagan dan pencabutan implan dan IUD dalam Permenkes 1464/Menkes/Per/x/2010 kewenangan pemasangan dan pencabutan IUD dan Implan hanya untuk bidan yang menjalankan program pemerintah, sedangkan untuk medapatkan rekomendasi IBI anggota harus mengikuti pelatihan CTU.

Peraturan-peraturan tidak boleh mengandung tuntutan yang melebihi apa yang dapat dilakukan.Peraturan tidak boleh sering berubah-ubah.Harus ada kecocokan antara peraturan yang diundang-undangkan dengan pelaksanaannya sehari-hari.

Kewajiban yang harus dipenuhi oleh warga negara atau pemohon yaitu dengan melengkapi persyaratan yang telahditentukan oleh peraturan perundang-undangan yang berlaku. ${ }^{21}$

2. Kendala-Kendala

Yang Menghambat Permohonan Surat Izin Praktik Bidan (SIPB) Berdasarkan Pera-turan Menteri Kesehatan Nomor 1464/ME NKES/PE R/X/2010

Tentang Izin Dan

Penyelenggaraan Praktik Bidan Di Kabupaten Brebes.

Robert B. Seidman menyatakan bahwa tindakan apapun yang akan diambil baik oleh pemegang peran, lembaga-lembaga pelak-sana maupun pembuat Undang-undang selalu berada dalam lingkup kompleksitas kekuatan-

21 Nur Yanto, 2015, Pengantar Hukum Administrasi Negara Indonesia, Mitra Wacana Medika, Jakarta, Hal.53 kekuatan sosial, budaya, ekonomi dan politik, dan lain sebagainya. Seluruh kekuatan-kekuatan sosial itu selalu ikut bekerja dalam setiap upaya untuk memfungsikan peraturan-peraturan yang berlaku, menerapkan sanksisanksinya, dan dalam seluruh aktivitas lembaga-lembaga pelaksanaannya. ${ }^{22}$

a) Hambatan dalam permohonan SIPB kaitannya dengan lembaga pembuat peraturan adalahPeraturan Menteri Kesehatan Nomor 1464/Menkes/Per /X/2010 tentang Izin dan Penyelenggaraan Praktik Bidan adalah peraturan terbaru yang meniadakan peraturan sebelumnya yaitu Keputusan Menteri Kesehatan Nomor 900/Menkes/SK/VII/2002 tentang Registrasi dan Praktik Bidan dan Peraturan Menteri Kesehatan Nomor

HK.02.02./Menkes/149///2010 tentang Izin dan Penyelenggaraan Praktik Bidan.

Berdasarkan Pasal 23 UU No. 36 Tahun 2009 Tentang Kesehatan bahwa tenaga kesehatan dalam menyelenggarakan pelayanan kesehatan, wajib memiliki izin dari pemerintah. Pasal 46 (1) UU Nomor 36 Tahun 2014 tentang Tenaga Kesehatan bahwa setiap tenaga kesehatan yang menjalankan praktik di bidang kesehatan wajib memilik izin.

Permohonan izin harus menempuh prosedur tertentu yag ditentukan oleh

22 Ibid, Hal.11 
pemerintah, selaku pemberi izin. Menurut Soehino, syarat-syarat dalam izin itu bersifat konstitusif dan kondisional. $^{23}$

a. Hambatan dalam permohonan SIPB kaitannya dengan penerapan peraturan adalah Dinas Kesehatan Kabupaten Brebes memberikan kebijakan dengan mengeluarkan dua kewenangan SIPB yaitu SIPB yang hanya melayani pemeriksaan kehamilan normal dan nifas normal (SIPB ANC/Ante Natal Caredan PNC/Post Natal care) dan SIPB yang melayanai pemeriksaan kehamilan normal dan persalinan dan nifas normal (SIPB ANC INC PNC/ Ante Natal Care, Intra Natal care dan P ost Natal Care).

Berdasarkan UU RI Nomor 36 Tahun 2009 Pasal 5 tentang Kesehatan bahwa: Setiap orang mempunyai hak yang sama dalam memperoleh akses sumber daya di bidang kesehatan; memperoleh pelayanan yang aman, bermutu dan terjangkau; serta mandiri dan

23 Bersifat konstitusif, oleh karena ditentukan suatu perbuatan atau tingkah laku tertentu yang harus (terlebih dahulu) dipenuhi, artinya dalam hal pemberian izin itu ditentukan suatu perbuatan konkret, dan bila tidak dipenuhi dapat dikenai sanksi. Bersifat kondisional, oleh karena penilaian tersebut baru ada dan dapat dilihat serta dapat dinilai setelah perbuatan atau tingkah laku yang disyaratkan itu terjadi. Penentuan prosedur dan persyaratan perizinan ini dilakukan secara sepihak oleh pemerintah, meskipun demikian, pemerintah tidak boleh menentukan prosedur dan persyaratan menurut kehendaknya sendiri, tetapi harus sejalan dengan peraturan perundang-undangan yang menjadi dasar dari perizinan tersebut. Ridwan HR, 2012, Op.Cit, hal. 160 bertangung jawab menentukan sendiri pelayanan kesehatan yang diperlukan bagi dirinya.

b. Hambatan yang berkaitan dengan pemangku peran adalah pengajuanpermohonan dan pembaruan SIPBdilakukan secara kolektif per ranting tiap kecamatan, yang tidak semua BPM masa berlaku SIPB berbeda. Kepatuhan setiap anggota untuk mengumpulkan persyaratan SIPB juga berbeda ada yang segera mengumpulkan dan ada juga yang lambat, hal ini yang menyebabkan proses pengajuan SIPB berlangsung lama. Perwakilan IBI ranting baru akan mengajukan SIPB ke IBI cabang Brebes setelah persyaratan terkumpul. Setiap anggota yang akan mengajukan permohonan SIPB harus melalui ranting terlebih dahulu untuk mendapatkan rekomendasi ketua ranting. Rekomendasi organisasi profesi sebagai salah satu syarat pembuatan SIPB.

Tuntutan ilmu hukum adalah pada pertanggungjawaban (culpability/ responsibility). Dari keseluruhan pertanyaan yang timbul adalah dibutuhkan suatu penjelasan yang bersifat sosiologis tentang bagaimana hubungan antara Permenkes 1464/menkes/Per/X/2010 tentang Izin dan Penyelenggaraan Praktik Bidan dengan pengaruh peraturan tersebut 
387 | Jurnal Idea Hukum

Vol. 2 No. 2 Oktober 2016

Magister Hukum Fakultas Hukum Universitas J enderal Soedirman

terhadap tindakan Bidan yang berkaitan

dengan wewenangnya. Salah satu kemungkinan penjelasannya adalah bahwa pelanggaran terhadap kewenangan bidan dalam kepemilikan SIPB dan pemasangan AKBK dan AKDR sering tidak dijatuhi sanksi yang cukup berat (is not punished often enough).

Bergesernya pelaksanaan
hukum dari tujuan yang semula
diinginkan oleh pembuat undang-
undang, dalam sosiologi hukum lazim
dinamakangoal displacement
(pembelokan tujuan) dan goal
substitution (penggantian tujuan).

\section{F. PENUTUP}

\section{Simpulan}

Permohonan Surat Izin Praktik Bidan di Kabupaten Brebes belum sepenuhnya sesuai dengan Permenkes nomor 1464/Menkes/Per/X/2010 tentang Izin dan Penyelenggaraan Praktik Bidan ditunjukkan dengan masih dicantumkannya Kepmenkes No 900/Menkes/SK/VII/2002 tentang Registrasi dan Praktik Bidan pada persyaratan tunduk dan patuh pada peraturan yang berlaku. Pasal 29 Permenkes nomor 1464/Menkes/Per/X/2010 tentang Izin dan Penyelenggaraan Praktik Bidan menyatakan bahwa Kepmenkes No 900/Menkes/SK/VII/2002 tentang Registrasi dan Praktik Bidan dicabut dan dinyatakan tidak berlaku.

Hambatan dari Permohonan Surat Izin Praktik Bidan berdasarkan Permenkes nomor 1464/Menkes/Per/X/2010 tentang Izin dan Penyelenggaraan Praktik Bidan di kabupaten Brebes adalah:

1. Untuk mendapatkan rekomendasi dari IBI anggota harus mengikuti pelatihan CTU.

2. Kepatuhan anggota dalam mengumpulkan persyaratan permohonan SIPB berbedabeda yang mengakibatkan proses pengajuan berlangsung lama.

3. Adanya kebijakan dari Dinas Kesehatan dan IBI Kabuptaen Brebes yang memberlakukan dua kewenangan SIPB ANC dan PNC dan SIPB ANC, INC dan PNC.

\section{Saran}

a. Dinas Kesehatan Kabupaten Brebes

1) Perlu merevisi tentang surat pernyataan tunduk terhadap peraturan agar mencantum-kan

Permenkes

1464/Menkes/Per/x/2010

bukan Kepmenkes 900/Menkes/SK/VII/2002.

2) Perlu mengkaji dan mempertimbangkan kembali ter- 
kait dengan kebijakan dua kewenangan SIPB ANC dan PNC dan SIPB ANC, INC dan PNC.

b. Pengurus cabang dan ranting Ikatan Bidan Indonesia (IBI) Kabupaten Brebes

$$
\text { Pada Permenkes }
$$

dinyatakan bahwa bidan boleh memasang AKDR di fasilitas pelayanan kesehatan pemerintah dengan supervisi dokter. Perlunya dipertimbang kan kembali mengenai keharusan mengikuti pelatihan CTU untuk mendapatkan rekomendasi IBI.

\section{Bidan Praktik Mandiri}

Agar selalu berpedoman

$\begin{array}{lr}\text { pada Permenkes } & \text { 1464/ } \\ \text { Menkes/Per/x/2010 sebagai } & \text { serbaru } \\ \text { peraturan terbang } \\ \text { mengatur tentang zin dan } \\ \text { penyelenggaraan }\end{array}$

Bidan.

\section{DAFTAR PUSTAKA}

Ali, Achmad dan Heryani Wiwie. 2012.Menjelajahi Kajian Empiris Terhadap Hukum. Prendamedia. Jakarta.

Amirudin dan Ashikin, Zainal.2004. Pengantar Metode Penelitian Hukum. PT. Raja Grafindo Persada. Jakarta.

Basah,Sjachran. 1995. Pencabutan Izin Sebagai Salah Satu Sanksi Hukum Administrasi Negara. FH UNAIR. Surabaya.

HR, Ridwan. 2003.Hukum Administrasi Negara. UII Press. Yogyakarta.
2008. Hukum Administrasi Negara. Raja Grafindo Persada. Jakarta.

Jaringan Nasional Pelatihan KlinikKesehatan Reproduksi. 2008. Pelatihan Klinik Asuhan Persalinan Normal. Jakarta.

Soerkanto, Soerjono. 2010. Pengantar Penelitian Hukum. UII Press. Jakarta. , 2011. Faktor faktor Yang mempengaruhi Penegakan Hukum. Rajawali Pers. Jakarta.

Soerkanto,Soerjono. dan Mamudji Sri. 2007. Penelitian Hukum Normatif Suatu Tinjauan Singkat. PT Raja Grafindo Persada. Jakarta.

Warasih, Esmi, 2011. Pranata Hukum Sebuah Telaah Sosiologis. PT. Suryandaru Utama. Semarang.

Yanto,Nur. 2015.Pengantar Hukum Administrasi Negara Indonesia. Mitra Wacana Medika. Jakarta.

Undang undang Dasar 1945

Undang-undang Nomor 12 Tahun 2011 tentang Peraturan Pembentukan Perundang-undangan

Undang-undang Nomor 36 Tahun 2009 Tentang Kesehatan.

Undang-undang Nomor 36 Tahun 2014 Tentang Tenaga Kesehatan

Keputusan Menteri Kesehatan Republik Indonesia Nomor 1464/MENKES/PER/X/2010 Tentang Izin dan Penyelenggaraan Praktik Bidan.

Peraturan Daerah Kabupaten Brebes No. 18 Tahun 2001 tentang Penyelenggaraan Sarana Pelayanan Kesehatan

http;//www.etikaprofesi. blogspot.com/2011/07/organisasiprofesi.html. diakses pada tanggal 3 April 2016.

Sophia, mega. $|\mathrm{B}|$ http://megasophianarh.blogspot.c o.id/2013/02/ibi-ikatan-bidanindonesia.html, diakses pada tanggal 5 April 2016.

Syafrudin Ateng, 2000, Menuju Penyelenggaraan Pemerintahan Negara yang Bersih dan bertanggung Jawab, Jurnal Pro Justisia, Edisis IV, Universitas Parahyangan, Bandung. 